\title{
62. 新しい単身用透析装置の使用経験
}

\author{
蟹由 斉* 柴田 猛* 三村信英* \\ 金子岩和*2 葛西浩美*2 太田和夫*2
}

\section{はじめに}

腎不全患者の血液透析に際して，個々の患者 の条件に応じて，透析液を選択でき，かつ， Dialyzerの限外沪過畫を正確に制御できれば， 患者快快適に透析を受汀られ，医療側も透析中 の管理が容易となる。このような目的で開発さ れた，西独・フレゼニュース社の単身用透析装 置 A-2008C につマて in vitro および臨床試験 を行ったので報告する(写真 1 ).

\section{I 装置の概要}

本装置は透析液供給機構, 限外沪過定量機構 および各種の患者監視機構より構成されてい る。

1）患者監視機構

血液ポンプ, ヘパリンポンプ, シングルニー ドル装置, エアーデテクター, 動脈圧計, 静脈 圧計など各種のアラーム計器を備えている。な

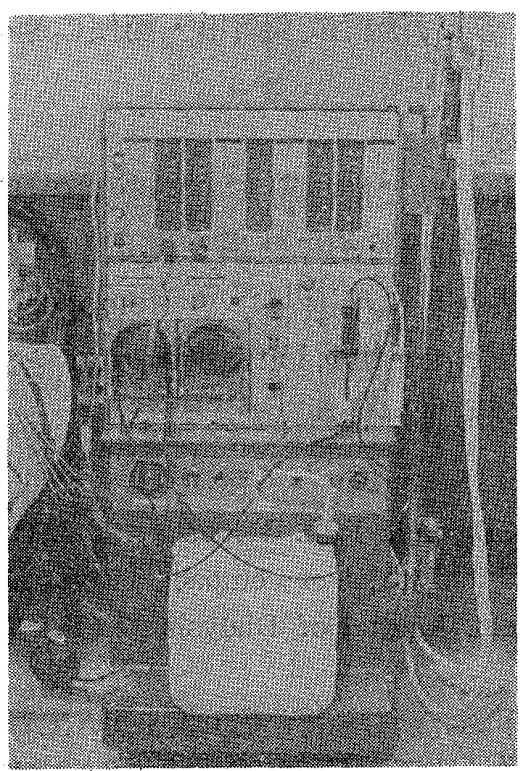

写真 1
おシングルニードル装置は電磁弁にて交互に開 閉する方式と異なり，静脈側回路にも血液ポン プを持ち，動静脈 2 台の血液ポンプにて血液を 出し入れする方式である.

2）透析液供給機構

透析液の希橎混合は透析液混合槽内の水位検 知フロートに連動された給水電磁弁により，常 に一定の水位に保たれる。透析液原液は混合槽 からの透析液の流出量, すなわち限外沪過定量 機構のバランシングチャンバーの動作に同期さ れた原液ポンプにて注入される。なお濃度の調 整注前面の濃度調製ダイヤルにて基隻值のー 6 $\% \sim+10 \%$ 範囲で調整が可能である.

3）限外沪過定量機構

本機構は 2 組のバランシングチャンバーを交 互に作動させ，給液と排液の量を完全に一致さ せる。限外汇過量の制御は汇過ポンプにて時間 当たり $1000 \mathrm{~m} l$ までは前面パネルの限外沪過設 定ダイアルで行い， $2000 \mathrm{~m} l$ までは任意の沪過 圧を設定して行ら：除水量はいずれも穦算カウ ンタで表示される。

\section{II in vitro 試験の方式・結果}

1）本装置の透析液濃度の安定性を，Na 濃度 にて経時的および経日的にみた，図 1 上段は， $\mathrm{Na}$ 濃度 $140 \mathrm{mEq} / \mathrm{L}$ の基準原液を使用し，6 時間 連続運転した時のもので経時的な透析液の $\mathrm{Na}$ 濃度は $139.9 \pm 0.7 \mathrm{mEq} / \mathrm{L}$ と安定している。下 段は $\mathrm{Na}$ 濃度 $137.5 \mathrm{mEq} / \mathrm{L}$ と $140 \mathrm{mEq} / \mathrm{L} の 2$ 種 類の基淮透析液原液を用い，それぞれ10週間の 透析液濃度の安定性をみたもので， $\mathrm{Na}$ 濃度ば $137.7 \pm 0.4 \mathrm{mEq} / \mathrm{L}, \quad 139.9 \pm 0.4 \mathrm{mEq} / \mathrm{L}$ 之優孔 た安定性ならびに再現性を示した。

2）限外沪過制御機構の定量性を実測量とカウ ンタ指示量でみた。 

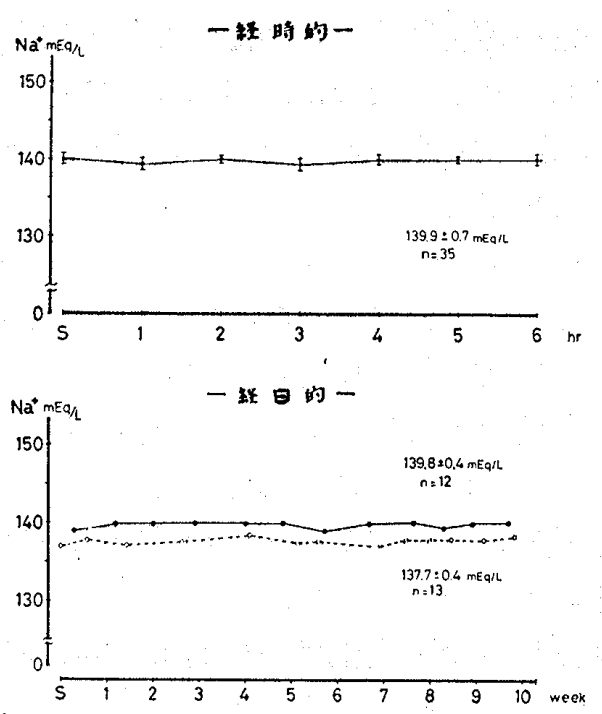

図 1 透析液濃度の安定性

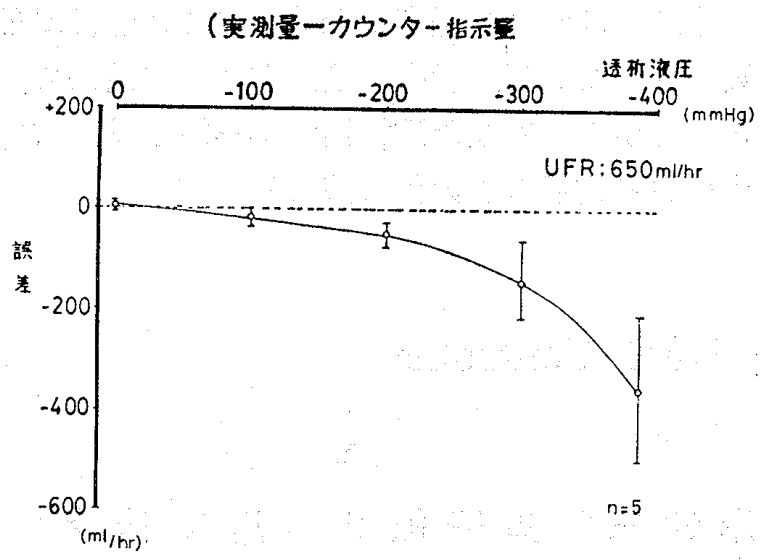

図 2 透析夜系回路内圧变化に伴う詿差

a）透析液圧の影響をみるため，透析液系の 回路内圧を $0,-100,-200,-300,-400 \mathrm{mmHg}$ に設定し, それぞれの圧で, 毎時 $650 \mathrm{~m} l$ の沪過を 行い実測量とカウンタ指示量との差をみたが陰 圧の上昇に伴い, 両者間の差は増大した(図2)。

b）限外沪過能 $3 \mathrm{ml} / \mathrm{mmHg} / \mathrm{hr}$ のdialyzer 使用乙， 6 時間の模凝透析に打ける汇過量の経 時的な推移をみた（図 3 )。上段の設定量每時 $1000 \mathrm{~m} l$ 透析液圧 $-200 \mathrm{mmHg}$ では害測量・カ ウンタ指示量とも低值であった，中段の沪過設 定量毎時 $600 \mathrm{ml}$ 透析液圧 $-100 \mathrm{mmHg}$ 下段の 汇過設定量每時 $200 \mathrm{~m} l$ 透析液圧 $-20 \mathrm{mmHg}$ で の汇過設定值に対するカウンタ指示量は，ほぼ 一致した。

III 臨床使用方法 ・ 結果

1）本装置による臨床使用66回での除水量と 変化量 (体重減少量, 食事量, 充填量で補正し
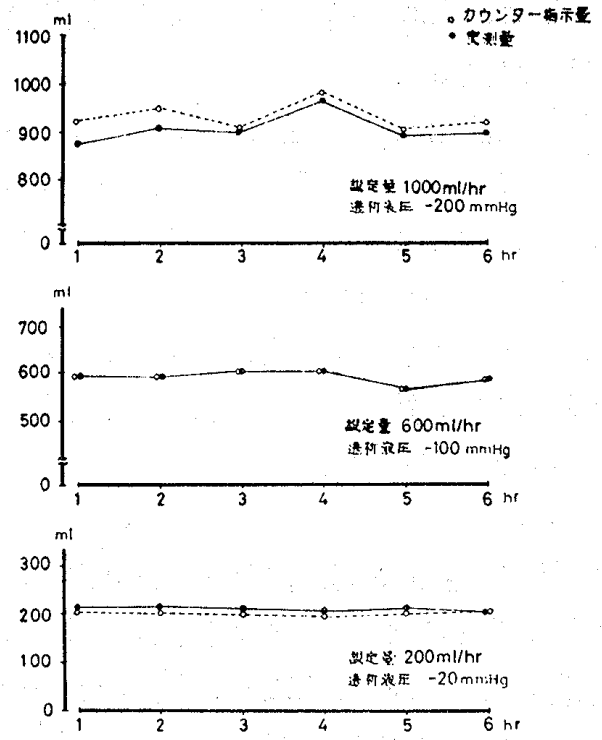

図 3 容量制御時におけるU.F.R.の安定性

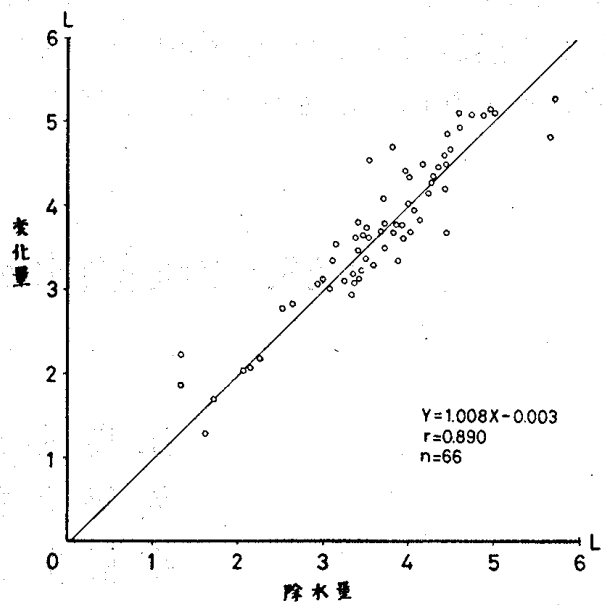

図 4 除水量と変化量の相関
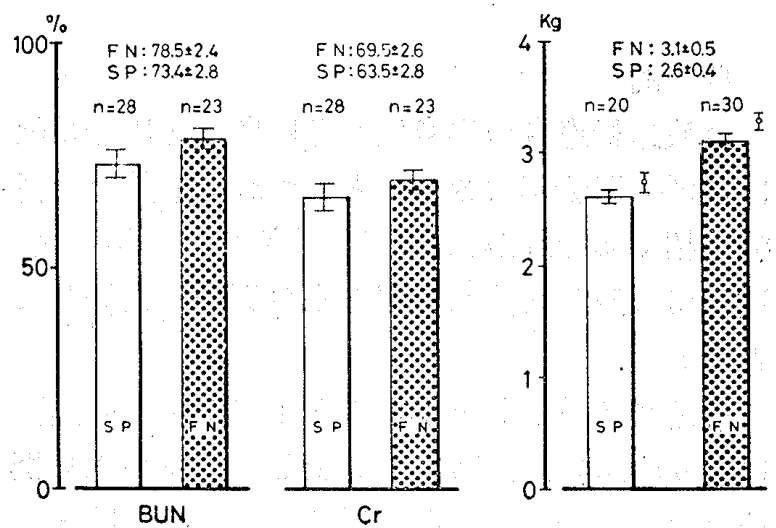

図 5 FRESENIUS とその他の装置 (S.P. 方式)での各種データの比較

た值)の相関関係は $\mathrm{r}=0.890$ であった(図 4).

2）本装置長期使用の 2 症例で,通常の single pass方式の装置と本装置を用いて治療した時の 
BUN, Greatinine の下降率および体重減少量 を比較した(図 5 ).

a）本装置使用時には通常の装置に比し BUN 下降率は，73.4\%が78.5\%に，また Creatinine 下降率注 $63.5 \%$ が $69.5 \%$ と, 約 7 10\%の透析 効率の改善が認められた。

b）通常の装置と本装置との間で，目標体重 減少量と塞質体重減少量と比較した，両者閒に 差は認められなかった。

\section{考 䕓}

1）限外汇過定量機構は，透析液陰圧により若 干の誤差を生じるが，これは装置の定量機構の 基本構造によるものではなく，透析液の脱気不 足が起因したものであり脱気の強化により，改 善され得る範囲と考える.

2）本装置に抢りる透析效率の改善は，透析液 の流れが脈動流であるため, dialyzer 内の透析 液の流れがより均一化されたためと考える。
3）通常の透析装置と本装置間で体重減少に差 が認められなかったのは，当施設では毎回 dialyzer の限外沪過量を実測し，透析の圧条件を 設定しているためと考える。

総 括

単身用透析装置 A-2008C について in vitro 試験および臨床使用を行った結果.

1. 本装置の透析液供給機の透析液濃度忹経時 的および経日的にも安定していた.

2. 本装置において $7 \sim 10 \%$ BUN, Creatinine下降率の改善がみられた。

3. 体重減少量と変化量の相関は $r=0.890$ で あり, 安定した除水が行われた。

\section{まटめ}

本装置は限外沪過定量機構など現在透析に必 要とされている患者監視装置をすべて備えてい ることから，安全な透析治療が実施し得，透析 中の患者監視の省力化が図れる。

\section{3. 計画除水が可能な UFR Controller}

$\begin{array}{ll}\text { 江良和雄* } & \text { 阿岸鉄三* 星野敏久* 島田浩幸* } \\ \text { 久保和雄* } & \text { 鈴木利昭* 太田和夫* 杉野信博*2 } \\ \text { 高橋芳 正*3 岡島 温*4 田中友康*4 加藤礼夫*4 } \\ \text { 彦坂幹雄*4 }\end{array}$

\section{目 的}

血液透析患者の過剩な水分貯留は循環器系統 に及ぼす影響が大きく，ともすれば重篤な合併 症を招く抢それがあり，日常生活の水分摂取量， 透析での適正な除水などの水分管理は大切なこ とである。

最近では High Flux のダイアライザの出現 により除水性能が著しく向上し，患者の水分捸 取量は楽になった区面，透析での的確な除水が 問題となり，UFR を Control する装置が開発

* 東京女子医科大学腎臟病総合医療センター透析室 *2. 東京女子医科大学内科 *3 練馬中央診療所人工透析センター *4 ムサシ・エンジニアリング怢
され臨床に使用されるようになってきている。 乙か乙現在の UFR Controller は総除水量を透 析時閒で割り出し，時閒当たりの除水速度を均 一に乙除水を行うため, 透析開始 $2 \sim 3$ 時間経 過後に血圧低下，もしくはショックをきたすこ とがある。

われわれはこれらの点を考慮し, UFR Control と microcomputer による除水速度制御装置 を組み合わせ，個々の患者に合った除水速度パ ターンが可能な UFR Controller を製作したの で報告する。

\section{I 材料および方法}

\section{1. 装置の構成}

本装置の構成は従来の透析用コンソールの機 